\title{
Evaluation of the feeding preference between the aquatic macrophytes Egeria densa and Chara indica by the invasive mollusk Melanoides tuberculata
}

\author{
E. L. Medeiros ${ }^{a}$ and G. G. Henry-Silva ${ }^{a}$ \\ áLaboratório de Limnologia e Qualidade de Água - LIMNOAQUA, Departamento de Ciências Animais, \\ Universidade Federal Rural do Semiárido - UFERSA, BR 47, Km 110, Bairro Presidente Costa e Silva, \\ CEP 59625-900, Mossoró, RN, Brazil \\ *e-mail: eudilena@hotmail.com
}

Received: May 26, 2015 - Accepted: February 11, 2016 - Distributed: May 31, 2017

(With 4 figures)

\begin{abstract}
This study evaluated the feeding preference of the invasive mollusk Melaniudes tuberculata between the aquatic macrophytes Egeria densa and Chara indica. The experiment consisted of twelve experimental units (glass aquariums) each of which contained three liters of water and three compartments. Fragments of $E$. densa and $C$. indica were placed in separate compartments within each unit; the third compartment, which did not contain macrophytes, was used as the control. Twenty Melanoides tuberculata individuals were placed in each unit and monitored hourly over the course of 24 hours for preferential movements. Physical and chemical water variables were measured at the beginning and end of the experiment. Habitat complexity was determined through collected macrophyte fragments and determined using the Fractop program. After 24 hours, the highest average number of individuals was observed in the treatment with Chara indica (ten individuals), which differed significantly from the treatment with $E$. densa (four individuals) and the control treatment (two individuals). The number of individuals between the $E$. dens $a$ and control treatment were similar. M. tuberculata showed a clear feeding preference for $C$. indica.
\end{abstract}

Keywords: habitat structure, gastropod, laboratory experiment.

\section{Avaliação da preferência do molusco invasor Melanoides tuberculata pelas macrófitas aquáticas Egeria densa e Chara indica}

\begin{abstract}
Resumo
O presente trabalho teve como objetivo avaliar a preferência do molusco invasor $M$. tuberculata pelas macrófitas aquáticas Egeria densa e Chara indica. Doze unidades experimentais (aquários de vidro), com dimensões de $30 \times 15 \times 15 \mathrm{~cm}$, subdivida em três compartimentos foram utilizadas. Em cada unidade experimental foram adicionados três litros de água, sendo que em dois compartimentos foram adicionados aleatoriamente fragmentos de $E$. densa e $C$. indica e um compartimento ficou sem planta (controle). Na parte central do aquário foram adicionados os moluscos equidistantes dos três compartimentos. O experimento teve duração de 24 horas, sendo vistoriado e contabilizado o número de organismos presentes em cada compartimento a cada hora. As variáveis ambientais foram medidas no inicio e fim do experimento. Fragmentos de macrófitas foram coletados para determinação da complexidade do habitat através do programa Fractop. Após 24 horas, os resultados mostraram um maior valor médio de indivíduos no tratamento que possuía Chara indica (dez indivíduos), que diferiu significativamente do tratamento com $E$. densa (quatro indivíduos) e do tratamento controle (dois indivíduos). Os tratamentos com E. densa e o controle foram semelhantes entre si evidenciando, uma possível preferência do molusco por a $C$. indica.
\end{abstract}

Palavras-chave: estrutura de habitat, gastrópode, experimento laboratorial.

\section{Introduction}

Studies on invasive species are becoming frequent due to the negative effects that these organisms can cause to the invaded environment. Invasive species can reduce and eliminate native species, induce mortality on species with commercial value through parasitic infections, and act as vectors of human diseases leading to public health issues (Fernández et al., 2003; Richardson et al., 2009; Krailas et al., 2014). Such problems have been observed in Brazil after the introduction of Melanoides tuberculata, a freshwater gastropod from Africa and Asia (Peso et al., 
2011). Melanoides tuberculata is an $r$ strategist ovoviviparous species that also reproduces by parthenogenesis. Therefore, it is able to maintain high population densities for long periods through high reproduction rates, rapid growth, and low mortality rates (Samadi et al., 1999; Andrade et al., 2012). Environmental ecological problems have been reported after its introduction to non-native environments (Schuster et al., 2014; Fernandez et al., 2014).

Hence, control of known negative effects caused by this species is dependent on the understanding factors such as its distribution, density, food availability and preference, water quality, and possible influence of organisms such as aquatic macrophytes that influence its successful colonization in a new environment (Mark, 2009; Fernández and Reid, 2012).

Aquatic macrophytes include plants from different groups such as microalgae, bryophytes, pteridophytes, and higher plants such as angiosperms (Thomaz and Esteves, 2011). They are an important food source for aquatic invertebrates providing periphyton to herbivores and dead organic material to detritivores (Thomaz and Esteves, 2011; Mormul et al., 2010; Fernández and Reid, 2012). Furthermore, macrophytes' colonization occurs in shallow environments, increases habitat complexity, and ultimately influences other aquatic assemblies by interfering in the density and biodiversity of native and exotic species such as mollusks (Thomaz et al., 2008; Thomaz and Cunha, 2010; Thomaz and Esteves, 2011).

The presence of freshwater mollusks can generate direct impacts on populations of aquatic macrophytes through known mutual relationships (Mormul et al., 2010). More specifically, mollusks obtain nutrients by consuming periphyton associated with macrophytes' foliage and reducing the effects of shading and competition for nutrients among these plants (Li et al., 2009; Mormul et al., 2010). Conversely, higher densities of gastropods negatively affect the growth of macrophytes because gastropods can change their feeding habits from periphyton to plant tissue (Li et al., 2009). Thus, studying the relationship between aquatic macrophytes and $M$. tuberculata can contribute to the understanding of their interactions and, consequently, how aquatic macrophytes influence the establishment and density of this gastropod's populations. This study evaluated the possible feeding preference of the invasive mollusk M. tuberculata for the submerged aquatic macrophytes Chara indica and Egeria densa.

\section{Material and Methods}

\subsection{Collection of environmental samples}

Samples of M. tuberculata, Chara indica, and Egeria densa, and water were collected in the Santa Cruz reservoir located in the semiarid region of Rio Grande do Norte ( $5^{\circ} 46^{\prime} 02.26^{\prime \prime} \mathrm{S}$ and $37^{\circ} 47^{\prime} 53.36^{\prime}$ ' W). Plant material and mollusks were placed in coolers with local water and transported to the laboratory. In the laboratory, mollusks were maintained in water tanks with constant aeration and temperature $\left(27^{\circ} \mathrm{C}\right)$.

\subsection{Experimental design}

Twelve glass aquariums were used as experimental units. Each unit $(30 \times 15 \times 15 \mathrm{~cm})$ was subdivided into three compartments corresponding to three treatments as described in Mormul et al. (2010). Four apical fragments of $E$. densa with six centimeters each were added to the first compartment; four fragments of $C$. indica with six centimeters each were added to the second compartment; no macrophytes was added to the third compartment (control). Three liters of water from the studied site were added to each aquarium. At the beginning of the experiment, 20 mollusks with an average length of $0.8 \mathrm{~cm}$ were placed in the center of each experimental unit and equidistant from the limits of the three compartments to allow free dislocation. The experiment was carried out for 24 hours and mollusk movements were observed and recorded hourly. The aquariums were maintained with constant aeration and temperature and a photoperiod of 12 hours. Aquariums were covered with black plastic bags to simulate the dark period.

\subsection{Determination of habitat complexity}

Four $20 \mathrm{~cm}$ long fragments of E. densa and four of C. indica were collected to determine habitat complexity. These fragments were placed in aquariums $(10 \times 10 \times 20 \mathrm{~cm})$ and photographed through the four lateral walls. These images were transferred to the Gimp program to be converted into black and white images to improve brightness and contrast. Black and white images were then transferred to the Fractop program (Cornforth et al., 2002) where the counting boxes method (grid limit method - Sugihara and May, 1990) was used to estimate the fractal dimension (D).

\subsection{Statistical analysis}

An ANOVA with repeated measures over time was used to evaluate the feeding preferences of Melanoides tuberculata (E. densa - treatment, $C$. indica - treatment, and control) during 24 hours; the Tukey's test was applied a posteriori. An ANOVA was used to evaluate the variation in the number of individuals in each treatment during 24 hours. The t-test was used to analyze differences in habitat complexities. All tests met the assumptions of normality and homogeneity according to the Shapiro-Wilk and Bartlett's testsand were carried out with a probability of $5 \%$.

\subsection{Environment variables}

The following limnological variables were measured at the beginning and end of the experiment: temperature, $\mathrm{pH}$, conductivity, turbidity, dissolved oxygen, and total dissolved solids (Table 1).

\section{Results}

\subsection{Evaluation of $M$. tuberculata feeding preferences in the course of 24 hours}

The number of $M$. tuberculata over the 24 hours experiment was always higher in the $C$. indica-treatment (average number of nine) than in the $E$. densa-treatment (average number of 
five) and control treatment. The control-treatment always showed the lowest number of individuals (average number of three). The number of M. tuberculata observed after eighth hours from the experiment start was significantly higher in the C.indica-treatment than in the E. densa-treatment and control. At the end of the experiment ( 24 hours), the average number of $M$. tuberculata was significantly higher in the $C$. indica-treatment (nine individuals) than in the E. densa-treatment and control. At 24 hours from the experiment start, the number of individuals in the E. densa-treatment (four) and control (two) were statistically similar (Figure 1).

Significant differences were observed in all analyzed treatments. The number of individuals in the C. indica-treatment was significantly higher in the dark period $(\mathrm{p}=0.006)$ whereas the number of individuals in the $E$. densa-treatment and control was significantly higher in the light period $(\mathrm{p}=0.000002$ and $\mathrm{p}=0.03$, respectively) (Figure 2 ).

No significant differences were observed in the number of individuals in each treatment over the analyzed 24 hours. The $C$. indica-treatment showed an average of eight individuals $(\mathrm{p}=0.3074)$, which did not significantly change during the 24 hour period (Figure 3A). The E. densa-treatment showed an average of five individuals and no significant changes $(p=0.1590)$ during the 24 hours of observation (Figure 3B). The control treatment showed an average of three individuals and no significant changes $(\mathrm{p}=0.4819)$ during the 24 hours of observation (Figure $3 \mathrm{~A}$ ).

\subsection{Evaluation of habitat complexity in $C$. indica and E. densa populations}

The average value of fractal dimension was significantly lower in C. indica (1.63) when compared to E. densa (1.81) (Figure 4).

The values of the physical and chemical variables monitored in the aquariums showed insignificant variation within the 24 hours experiment.

\section{Discussion}

This study evaluated the possible feeding preference of the invasive mollusk $M$. tuberculata for the submerged aquatic macrophytes Chara indica and Egeria densa.

$M$. tuberculata showed feeding preference for $C$. indica, suggesting a preference for perifiton attached to aquatic macrophytes. $C$. indica also serves as a refuge from predators. It has been reported that the biomass of the aquatic macrophyte Elodea canadenses shows a positive correlation with the richness of aquatic invertebrates because it creates an environment that provides a source of food and refuge from predators (Fernández and Reid, 2012).

Over the course of the 24-hour experimental period, $M$. tuberculata showed a preference for the aquatic macrophyte that had lower habitat complexity (C. indica). Thomaz and Cunha (2010) describe that aquatic macrophytes with high habitat complexity are associated with increased benthic fauna diversity. High habitat complexity allows for increased food availability and variety, providing an

Table 1. Mean values and standard deviation of physical and chemical variables in the aquariums throughout the 24 hours experiment.

\begin{tabular}{lcccccc}
\hline & Temp. & pH & Cond. & Turb. & D. O. & T.D.S. \\
\hline Mean & 26. & 5.9 & 0.34 & 5.4 & 7.8 & 0.22 \\
Standard Deviation & 0.4 & 0.0 & 0.01 & 0.9 & 1.3 & 0.00 \\
\hline
\end{tabular}

Temp. - temperature $\left({ }^{\circ} \mathrm{C}\right)$; $\mathrm{pH}$; Cond. - conductivity $\left(\mathrm{mS} . \mathrm{cm}^{-1}\right)$; Turb. - turbidity (NTU); D.O. - dissolved oxygen (mg. $\left.\mathrm{L}^{-1}\right)$; and T.D.S - Total dissolved solids (g. $\left.\mathrm{L}^{-1}\right)$.

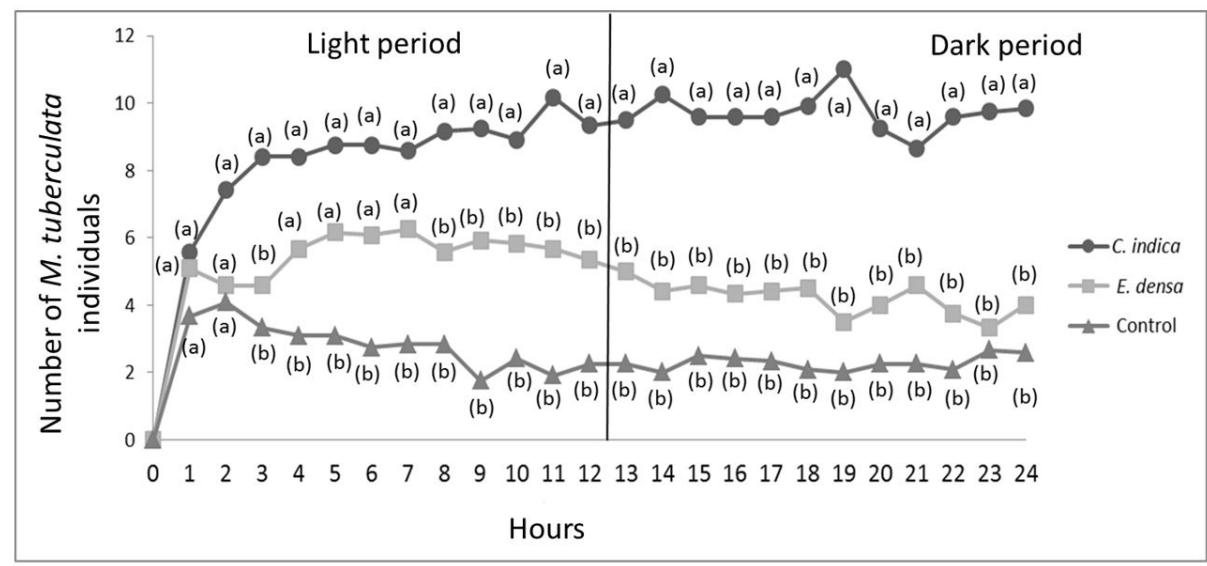

Figure 1. Mean values of the number M. tuberculata individuals in the treatments with C. indica, E. densa, and control. Different letters indicate significant difference between treatments by the Tukey's test. 


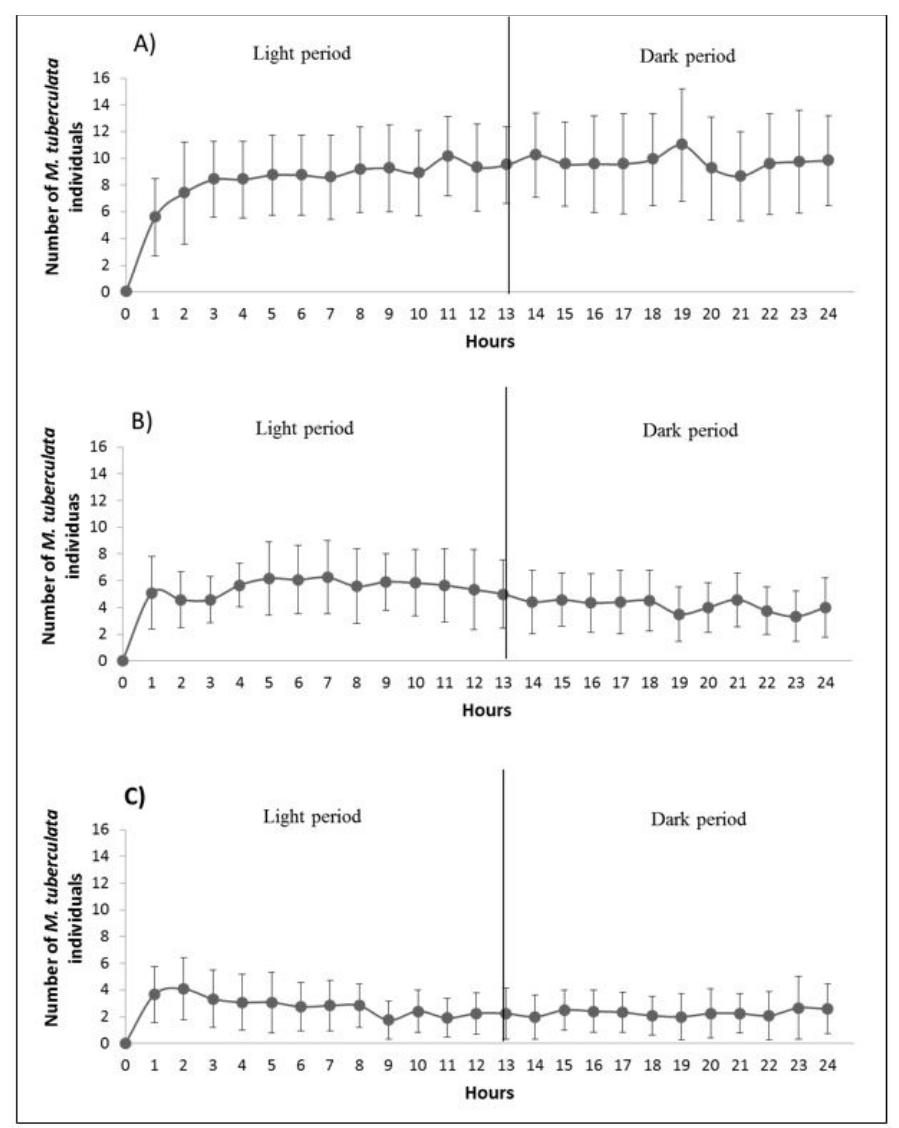

Figure 2. Mean values and standard deviation of the number of individuals of Melanoides tuberculata observed in the light and dark periods based on the t-test comparison. The different letters show significant differences in the number of individuals between periods. (A) treatment with $C$. indica; (B) treatment with E. densa; (C) control treatment.

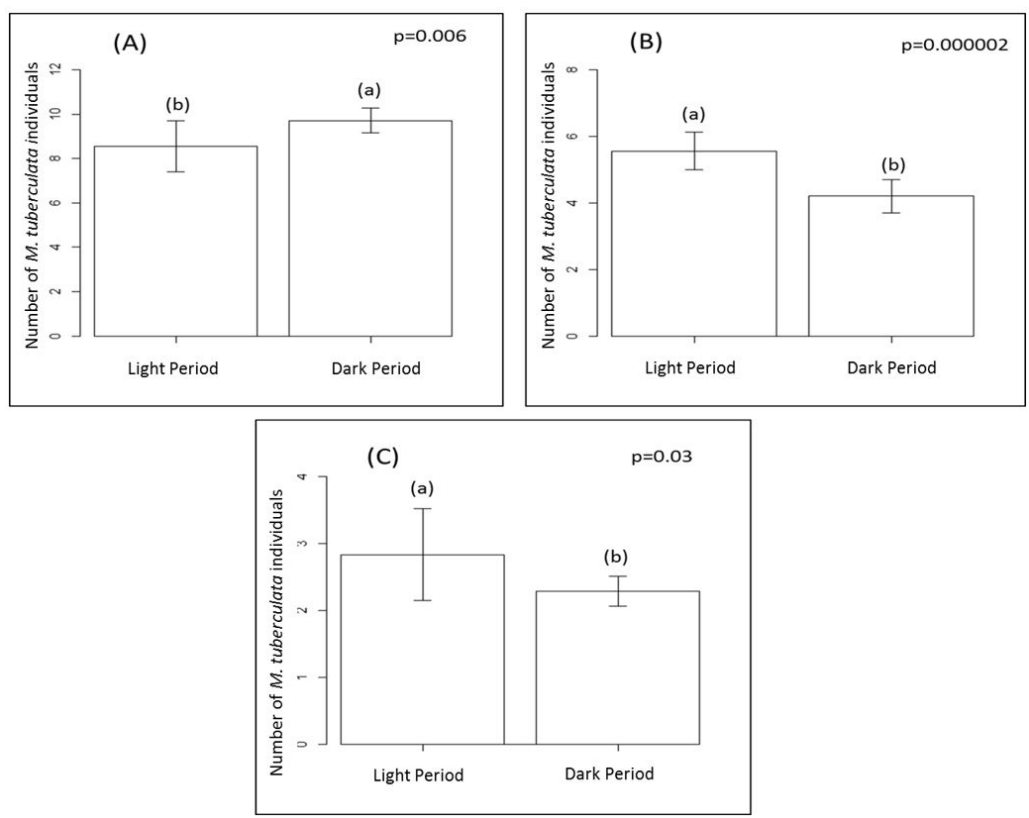

Figure 3. Mean values and standard deviations of the number of $M$. tuberculata individuals in the treatments with $C$. indica, E. densa, and control during 24 hours of observation. (A) C. indica; (B) E. densa; (C) Control. 


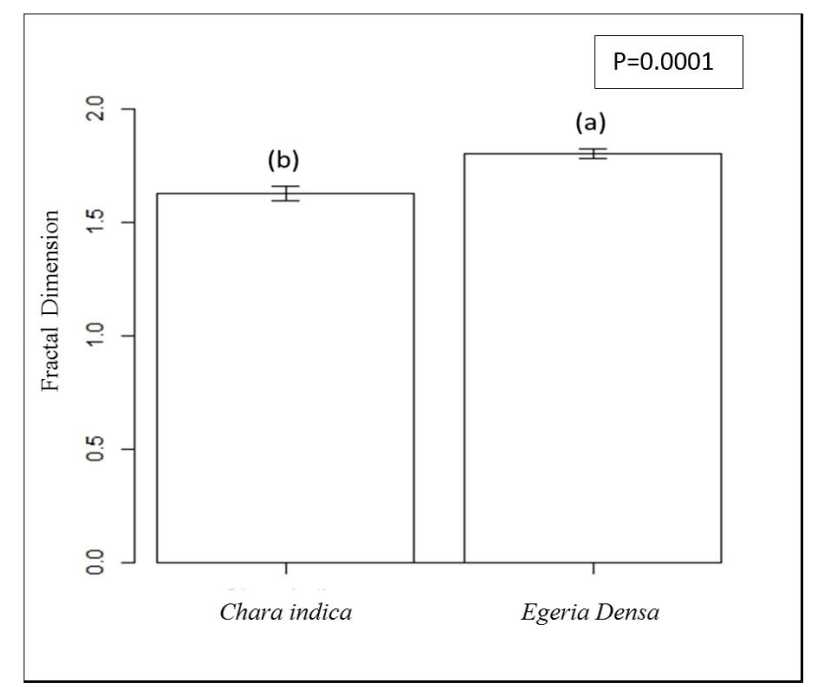

Figure 4. Mean values and standard deviation of fractal dimension figures determined in C. indica and $E$. densa populations in the studied region and based on the t-test comparing habitat complexity. Different letters show significant differences in the fractal dimension results between the two macrophyte species.

expanded range of micro-habitats. The same study also describes that structures of macrophytes populations have a decisive role in aquatic invertebrate communities (Thomaz and Cunha, 2010). Furthermore, populations of macrophyte species with high habitat complexities house enhanced macroinvertebrate diversity. Similarly, less complex environments are inhabited by a smaller number of organisms and species diversity is lessened reducing competition. In this study, results showed different habitat complexity between the studied macrophytes, which may have influenced the feeding preference of $M$. tuberculate as demonstrated by the different occurrences and densities between the studied treatments. The highest density of $M$. tuberculate was observed in the treatment containing the macrophyte with the lowest habitat complexity (C. indica), which could explain the preference for environments with less diversity and, consequently, less competition for space and food.

No significant differences in the number of individuals were observed between the light or dark periods. A study utilizing species of tropical gastropods determined that photoperiod was a determining factor for locomotion and abundance of the studied organisms (Liboriussen et al., 2005), results not in agreement with those of this study. Furthermore, these authors observed an increased activity of mollusks during light periods, which could result from increased photosynthetic rates related to increased periphyton growth rates. Ultimately, periphyton growth leads to food availability for mollusks (Liboriussen et al., 2005). Aufderheide et al. (2006) observed that increased activity occurs primarily during the nocturnal period and suggested that it could be related to a decreased visualization of prey by predators, which represents safer foraging (Aufderheide et al., 2006). Our results in each treatment did not show significant differences in movement of $M$. tuberculate between light and dark periods, which suggest that the feeding preference was not influenced by the light or dark condition. Nevertheless, the light period shows increased availability of food whereas the dark period provides less likelihood of predation and safer foraging.

In the present study, the invasive mollusk Melanoides tuberculata shows feeding preference for the aquatic macrophyte Chara indica compared to Egeria densa. Because the studied population of Chara indica showed lower habitat complexity than that of Egeria densa, it could more advantageous for the development of small organisms such as $M$. tuberculata.

\section{References}

ANDRADE, P.C., PINTO, H.A., COSCARELLI, D., VIDIGAL, T.H.D.A. and MELO, A.L., 2012. The natural infection of Melanoides tuberculata (Müller, 1774) (Mollusca: Gastropoda) by Centrocestus formosanus (Nishigori, 1924) (Platyhelminthes: Trematoda) in Paranoá lake, Brasília, Brazil. Brazilian Journal of Biology $=$ Revista Brasileira de Biologia, vol. 72, no. 2, pp. 419-420. http://dx.doi.org/10.1590/S1519-69842012000200026. PMid:22735153.

AUFDERHEIDE, J., WARBRITTON, R., POUNDS, N., FILEEMPERADOR, S., STAPLES, C., CASPERS, N. and FORBES, V., 2006. Effects of husbandry parameters on the life-history traits of the apple snail, Marisa cornuarietis: effects of temperature, photoperiod, and population density. Invertebrate Biology, vol. 125, no. 1, pp. 9-20. http://dx.doi.org/10.1111/j.1744-7410.2006.00035.x. PMid:19009043.

CORNFORTH, D., JELINEK, H. and PEICHL, L., 2002. Fractop: a tool for automated biological image classification. In: Proceedings of the 6th Australasia-Japan Joint Workshop, 2002, Canberra, Australia. Canberra: Australian National University, pp. 141-148.

FERNÁNDEZ, H.H. and REID, B., 2012. Invertebrate distribution on a macroalgae/macrophyte mixed mat in flowing water. 
Fundamental and Applied Limnology, vol. 181, no. 4, pp. 289299. http://dx.doi.org/10.1127/1863-9135/2012/0373.

FERNANDEZ, M.A., MATTOS, A.C., SILVA, E.F., SANTOS, S.B. and THIENGO, S.C., 2014. Malacological survey in the Manso Power Plant, State of Mato Grosso, Brazil: new records of freshwater snails, including transmitters of schistosomiasis and exotic species. Revista da Sociedade Brasileira de Medicina Tropical, vol. 47, no. 4, pp. 498-506. http://dx.doi.org/10.1590/00378682-0138-2014. PMid:25229292.

FERNÁNDEZ, M.A., THIENGO, S.C. and SIMONE, L.R.L., 2003. Distributioon of introduced freshwater snail Melanoides tuberculatus (Gastropoda: Thiaridae) in Brazil. The Nautilus, vol. 117 , no. 3 , pp. $78-82$.

KRAILAS, D., NAMCHOTE, S., KOONCHORNBOON, T., DECHRUKSA, W. and BOONMEKAM, D., 2014. Trematodes obtained from the thiarid freshwater snail Melanoides tuberculata (Müller, 1774) as vector of human infections in Thailand. Zoosystematics and Evolution, vol. 90, no. 1, pp. 57-86. http:// dx.doi.org/10.3897/zse.90.7306.

LI, K.-Y., LIU, Z.-W. and GU, B.-H., 2009. Density-dependent effects of snail grazing on the growth of a submerged macrophyte, Vallisneria spiralis. Ecological Complexity, vol. 6, no. 4, pp. 438442. http://dx.doi.org/10.1016/j.ecocom.2009.08.001

LIBORIUSSEN, L., JEPPESEN, E., BRAMM, M. and LASSEN, M.F., 2005. Periphyton-macroinvertebrate interactions in light and fish manipulated enclosures in a clear and a turbid shallow lake. Aquatic Ecology, vol. 39, no. 1, pp. 23-39. http://dx.doi. org/10.1007/s10452-004-3039-9.

MARK, A.D., 2009. Invasion biology. Oxford: Oxford University Press. 288 p. Oxford Biology.

MORMUL, R.P., THOMAZ, S.M., SILVEIRA, M.J. and RODRIGUES, L., 2010. Epiphyton or macrophyte: which primary producer attracts the snail Hebetancylus moricandi? American Malacological Bulletin, vol. 28, no. 1-2, pp. 127-133. http:// dx.doi.org/10.4003/006.028.0205.
PESO, J.G., PÉREZ, C.D. and VOGLER, R.E., 2011. The invasive snail Melanoides tuberculata in Argentina and Paraguay. Limnologica, vol. 1, no. 4, pp. 281-284. http://dx.doi.org/10.1016/j. limno.2010.12.001.

RICHARDSON, J., ARANGO, C.P., RILEY, L.A., TANK, J.L. and HALL, R.O., 2009. Herbivory by an invasive snail increases nitrogen fixation in a nitrogen limited stream. Canadian Journal of Fisheries and Aquatic Sciences, vol. 66, no. 8, pp. 1309-1317. http://dx.doi.org/10.1139/F09-079.

SAMADI, S., MAVÁREZ, J., POINTIER, J.P., DELAY, B. and JARNE, P., 1999. Microsatellite and morphological analysis of population structure in the parthenogenetic freshwater snail Melanoides tuberculata: insights into creation of clonal variability. Molecular Ecology, vol. 8, no. 7, pp. 1141-1153. http://dx.doi. org/10.1046/j.1365-294x.1999.00671.x. PMid:10447855.

SCHUSTER, R.K., ALDHOUN, J.A. and O'DONOVAN, D., 2014. Gigantobilharzia melanoidis n.sp. (Trematoda: Schistosomatidae) from Melanoides tuberculata (Gastropoda: Thiaridae) in the United Arab Emirates. Parasitology Research, vol. 113, no. 3, pp. 959-972. http://dx.doi.org/10.1007/s00436-013-3728-1. PMid:24322292.

SUGIHARA, G. and MAY, R., 1990. Applications of fractals in ecology. Trends in Ecology \& Evolution, vol. 5, no. 3, pp. 79-86. http://dx.doi.org/10.1016/0169-5347(90)90235-6. PMid:21232328.

THOMAZ, S.M. and CUNHA, E.R., 2010. The role of macrophytes in habitat structuring in aquatic ecosystems: methods of measurement, causes and consequences on animal assemblages composition and biodiversit. Acta Limnologica Brasiliensia, vol. 22, no. 2, pp. 218-236. http://dx.doi.org/10.4322/actalb.02202011.

THOMAZ, S.M. and ESTEVES, F.A., 2011. Comunidade de macrófitas aquáticas. In: F.A. ESTEVES. Fundamentos de limnologia. 3rd ed. Rio de Janeiro: Interciência. 826 p.

THOMAZ, S.M., DIBBLE, E.D., EVANGELISTA, L.R., HIGUTI, J. and BINI, L.M., 2008. Influence of aquatic macrophyte habitat complexity on invertebrate abundance and richness in tropical lagoons. Freshwater Biology, vol. 53, pp. 358-367. 